\title{
RIKEN NATURAL RADIOCARBON MEASUREMENTS V
}

\author{
FUMIO YAMASAKI, TATSUJI HAMADA, \\ and CHIKAKO HAMADA
}

\author{
Institute of Physical and Chemical Research (RIKEN) \\ Komagome, Bunkyo-ku, Tokyo, Japan
}

The $\mathrm{C}^{14}$ dates given below are a continuation of the work presented in our previous list (Radiocarbon, 1968, v. 10, p. 333-345), and have been obtained by counting $\mathrm{CO}_{2}$ at ca. 2 atm pressure in a $2.7 \mathrm{~L}$ stainless steel counter. Results obtained mainly during 1968 are described.

Dates have been calculated on the basis of the $\mathrm{C}^{14}$ half-life of 5568 yr and $95 \%$ of NBS oxalic acid as modern standard.

\section{SAMPLE DESCRIPTIONS}

\section{GEOLOGIG SAMPLES}

\section{N-473. Midorikawa Dam}

$$
\text { A. Japan }
$$

Charred wood ca. $50 \mathrm{~m}$ from entrance of an adit dug into $\mathrm{R}$ bank of Midorikawa Dam site, Kejono, Tomochi-machi, Shimomashiki-gun, Kumamoto pref. (32 $37^{\prime} \mathrm{N}$ Lat, $130^{\circ} 55^{\prime} \mathrm{E}$ Long), from welded tuff, ca. $30 \mathrm{~m}$ below surface, from Aso volcano overlying dioritic gneiss. Coll. and subm. 1968 by K. Kojima, Public Works Research Inst.

\section{N-474. Kozoji}

Charred wood found at Kozoji, Kasugai city, Aichi pref. $\left(35^{\circ} 16^{\prime}\right.$ $\mathrm{N}$ Lat, $137^{\circ} 03^{\prime} \mathrm{E}$ Long), from upper of 2 wood layers between cemented gravel, sand, and silt overlapping Paleozoic sandstone. Coll. 1968 by $\mathrm{H}$. Iijima; subm. by K. Kojima. Comment (K.K.): date gives rate of cementation.

\section{Tonokawa series}

Wood ca. $30 \mathrm{~m}$ from entrance of an adit dug into bank of Tonokawa River $8 \mathrm{~m}$ above river bed, Nakayama, Ikeda-machi, Shodo-gun, Kagawa pref. (34 $30^{\prime} \mathrm{N}$ Lat, $134^{\circ} 15^{\prime} \mathrm{E}$ Long), from landslide debris overlying weathered granite, arkose sand stone. Coll. 1968 by S. Akutagawa; subm. by K. Kojima.

\section{N-486-1. Tonokawa 1}

N-486-2. Tonokawa 2

\section{N.460. Kuwae}

$35,500 \pm 2400$

Charred wood washed out from silt, $5 \mathrm{~m}$ below surface, overlain by sand and gravel, at $\mathrm{R}$ bank of Kuwae River, $1 \mathrm{~km} \mathrm{~W}$ of Kuwae, Kurokawa-mura, Kita-Kanbara-gun, Niigata pref. $\left(38^{\circ} 04^{\prime} \mathrm{N}\right.$ Lat, $139^{\circ} 0^{\prime}$ E Long). Coll. 1967 by N. Oyagi and T. Uchida; subm. by Oyagi, Natl. Research Center for Disaster Prevention. 


\section{N-386. Nikko}

Peaty soil from 180 to $120 \mathrm{~cm}$ below surface, at Nikko High School, Kujira-machi, Nikko city, Tochigi pref. ( $36^{\circ} 45^{\prime} \mathrm{N}$ Lat, $139^{\circ} 35^{\prime} \mathrm{E}$ Long). Soil layer overlain by Imaichi pumice and Shichihonzakura pumice flow from volcano Nantai and underlain by sandy volcanic ash. Coll. 1967 by J. Akutsu, Utsunomiya Univ.; subm. by M. Oishi, Natl. Research Center for Disaster Prevention. Comment (J.A.): according to stratigraphic consideration with Kanto Loam in Gumma area, pumice flow is estimated at ca. 10,000 yr B.P.

\section{N-515. Ikadaba}

$3290 \pm 120$

1340 B.C.

Part of timber (cryptomeria japonica) unearthed by landslide due to Kanogawa typhoon in 1958, at Ikadaba, Naka-Izu-machi, Tagata-gun, Shizuoka pref. (34 $54^{\prime}$ N Lat, $139^{\circ} 58^{\prime}$ E Long). Coll. 1959 and subm. by H. Kihara, Natl. Inst. of Genetics.

\section{N-516. Ashinoyu}

$4970 \pm 130$

3020 в.C.

Wood fragment (cryptomeria japonica) from loam, ca. $10 \mathrm{~m}$ below surface, at Ashinoyu, Hakone-machi, Ashigarashimo-gun, Kanagawa pref. (35 $15^{\circ} \mathrm{N}$ Lat, $139^{\circ} 03^{\prime} \mathrm{E}$ Long). Coll. 1967 by Y. Ota; subm. by $\mathrm{H}$. Kihara.

\section{N-507. Naruto Strait}

$995 \pm 110$

Coral (Dendrophyllia cribrosa) caught in fishing net from bottom at $>100 \mathrm{~m}$ deep at Naruto Strait $\left(34^{\circ} 13^{\prime} \mathrm{N}\right.$ Lat, $134^{\circ} 41^{\prime} \mathrm{E}$ Long). Probable fossil material exposed on sea bottom. Coll. by U. Yasui; subm. 1968 by H. Ozaki, Natl. Sci. Mus. Comment: material possibly contaminated with recently deposited carbonates.

\section{N-508. Inbanuma}

$>\mathbf{3 7 , 8 0 0}$

Charred wood from cliff of artificial channel for water resources, Seto, Inba-mura, Inba-gun, Chiba pref. (35 $47^{\prime} \mathrm{N}$ Lat, $140^{\circ} 14^{\prime} \mathrm{E}$ Long). Sample from light yellowish gray gravel and sand bed with elephant fossil, Palaeoloxodon naumanni (MAKIYAMA), and $25 \mathrm{~m}$ below ground surface. Overlain by thick shell bed, loam, and surface soil. Coll. by Y. Hasegawa; subm. 1968 by H. Ozaki.

\section{N-509. Umigami}

$$
2430 \pm 120
$$

\section{0 в.C.}

Fossil timber from deposits in temporarily dammed small valley at Umigami, Onsen-cho, Mikata-gun, Hyogo pref. (35 $30^{\prime} \mathrm{N}$ Lat, $134^{\circ} 26^{\prime}$ $\mathrm{E}$ Long). Assoc. with fossil leaves indicating colder climate than at present. Coll. 1966 and subm. by H. Ozaki.

\section{N-510. Akabanedai}

$6210 \pm 140$

$$
4260 \text { в.c. }
$$

Wood from loamy clay layer of alluvium at $6.5 \mathrm{~m}$ depth at Akabanedai 8-1, 3 chome, Kita-ku, Tokyo ( $35^{\circ} 44^{\prime} \mathrm{N}$ Lat, $139^{\circ} 43^{\prime} \mathrm{E}$ Long). 
Overlain by peat. Coll. 1968 by K. Kawano and I. Fujiyama; subm. by H. Ozaki.

\section{N-511. Kidodai}

Peat intercalated in uppermost part of Myoko Formation at Kidodai, Sosagun, Chiba pref. (35 $41^{\prime} \mathrm{N}$ Lat, $141^{\circ} 27^{\prime} \mathrm{E}$ Long). Coll. 1968 by F. Ueda and I. Fujiyama; subm. by H. Ozaki.

\section{N-512. Hachioji}

Trunk of wood (Metasequoia distans), in situ, exposed on river bed of Asakawa in Narahara, Hachioji-city, Tokyo $\left(35^{\circ} 40^{\prime} \mathrm{N}\right.$ Lat, $139^{\circ} 24^{\prime} \mathrm{E}$ Long). Coll. 1967 and subm. by H. Ozaki.

\section{N-513. Ikenohata}

Wood from Tokyo Bed, discovered during underground railway construction near Shichiken-cho, Ikenohata (Shinobazu-no-ike), Taito-ku, Tokyo (35 $42^{\prime} \mathrm{N}$ Lat, $139^{\circ} 46^{\prime} \mathrm{E}$ Long), assoc. with elephant, Palaeoloxodon naumanni (MAKIYAMA). Coll. and subm. by H. Ozaki.

\section{B. Taiwan}

\section{Fossil coral series, Taiwan}

Fossil hermatypic corals from various localities in Taiwan. Coll. 1966 and subm. by K. Konishi, Kanazawa Univ. Some samples are also dated by ionium and protactinium method at Kanazawa Univ. (Konishi, Omura, and Kimura, 1968; Omura, Konishi, and Hamada, 1969).

\section{N-407. Hualien (CT-1)}

Platygyra phyrygia from outcrop of reef-wall limestone, $\mathbf{8 5 0}$ B.C. ca. $1.3 \mathrm{~km}$ WNW of Hualien city, Hualien-hsien $\left(24^{\circ} 01^{\prime} \mathrm{N}\right.$ Lat, $121^{\circ}$ $38^{\prime}$ E Long). Material believed to belong to Milun raised coral reef. Io age: $4200 \pm 370$. Comment (K.K.): traces of calcite have been detected by X-ray diffraction analysis.

\section{N-399. K'enting 1 (CT-2)}

Goniastrea pectinata among cobbles consisting K'enting Becl, at $+14 \mathrm{~m}$ in schoolyard of K'enting Primary School, K'enting, Hengchungchen, Pingtung-hsien ( $21^{\circ} 57^{\prime} \mathrm{N}$ Lat, $120^{\circ} 48^{\prime} \mathrm{E}$ Long). Io age: $6300 \pm$ 380 and $6300 \pm 520$. Pa age: $7300 \pm 700$ and $6900 \pm 500$.

\section{N-400. K'enting 2 (CT-3)}

$3790 \pm 120$

Favites abdita, different cobble from same site as N-399. Io age: 6300 \pm 280 .

\section{N-401. Shih-niu Chiao 1 (CT-4)}

Coral head (Favia sp.) of ca. $20 \mathrm{~cm}$ in diam in growth position, $+15 \mathrm{~m}$, at road-cutting ca. $200 \mathrm{~m}$ SW of Shih-niu Chiao, Hengchungchen, Pingtung-hsien (21 $57^{\prime} \mathrm{N}$ Lat, $120^{\circ} 47^{\prime} \mathrm{E}$ Long), in bed lithologi- 
cally different from K'enting Bed at same type locality, but believed correlative. Io age: $8200 \pm 500$. Pa age: $8000 \pm 400$.

\section{N-402. Shih-niu Chiao 2 (CT-5)}

Coral head (Porites compressa) of ca. $1 \mathrm{~m}$ in diam. in bluish gray mud of same unnamed bed as N-401 near Shih-niu Chiao, only a few $\mathrm{m} \mathrm{E}$ of $\mathrm{N}-401$. Io age: $6300 \pm 300$.

\section{N-445. Taitung (CT-6)}

Unidentifiable coral head of cobble size from emerged coral reefs, Houtzushan, ca. $6 \mathrm{~km} \mathrm{NE}$ of Taitung ( $\left(22^{\circ} 48^{\prime} \mathrm{N}\right.$ Lat, $121^{\circ} 10^{\prime} \mathrm{E}$ Long), at ca. +20 m. Reef may be correlated with Milun Bed. Comment (K.K.): material has been altered diagenetically and ca. $5 \%$ calcite has been detected.

\section{N-404. Fengchang 1 (CT-7)}

$5040 \pm 125$

Coral heads (Favia speciosa) of ca. $50 \mathrm{~cm}$ in diam. in growth position, at outcrop of Fengchang raised coral reef along main highway ca. $2 \mathrm{~km}$ SSE of Fengchang, Fangshan-hsiang, Pingtung-hsien $\left(22^{\circ} 10^{\prime}\right.$ $\mathrm{N}$ Lat, $120^{\circ} 41^{\prime} \mathrm{E}$ Long), at $+20 \mathrm{~m}$. Io age: $6300 \pm 260$.

\section{N-405. Fengchang 2 (CT-8)}

$5110 \pm 135$

3160 B.c.

Coral head (Favia pallida) of ca. $50 \mathrm{~cm}$ in diam. from same site as N-404. Io age: $5500 \pm 340$ and $5200 \pm 170$. Pa age: $9400 \pm 1700$.

\section{N-446. Oluanpi (CT-9')}

$3600 \pm 120$

Piece of coral head (Favia sp.) of ca. $20 \mathrm{~cm}$ in diam. from Oluanpi Limestone at Oluanpi, Hengchun-chen, Pingtung-hsien $\left(21^{\circ} 52^{\prime} \mathrm{N}\right.$ Lat, $120^{\circ} 52^{\prime}$ E Long). Coll. by T. Y. H. Ma, Natl. Taiwan Univ.; subm. by K. Konishi. Comment (K.K.): X-ray confirmed $4 \%$ calcite.

\section{N-406. Shanhai-li}

$4810 \pm 120$

Goniastrea sp. amidst rounded cobbles ca. $15 \mathrm{~cm}$ in diam. from gravel bed at schoolyard of Shanhai-li Primary School, ca. $3.7 \mathrm{~km}$ WSW of Hengchung, Henchung-chen, Pingtung-hsien (21 $59^{\prime} \mathrm{N}$ Lat, $120^{\circ} 42^{\prime}$ $\mathrm{E}$ Long), at ca. $+12 \mathrm{~m}$. Bed may be correlated with K'enting Bed to $\mathrm{S}$. Comment (K.K.): $<5 \%$ calcite detected.

\section{N-447. Shih-niu Chiao 3 (CT-10)}

$1730 \pm 110$

Favites sp. of ca. $10 \mathrm{~cm}$ in diam. in growth position, at $+1.5 \mathrm{~m}$. (mean) at emerged coral reef, ca. $250 \mathrm{~m}$ SWS of Shih-niu Chiao, Hengchung-chen, Pingtung-hsien (21 $57^{\prime} \mathrm{N}$ Lat, $120^{\circ} 47^{\prime} \mathrm{E}$ Long). Reef may be younger than "Shih-niu Chiao Bed." Io age: $2100 \pm 140$. Pa age: $3300 \pm 300$. 
N-403. Shih-niu Chiao 4

$1660 \pm 105$

Unidentified coral from same site as N-447.

\title{
C. Great Britain
}

\section{N-475. Cardross}

\author{
$11,900 \pm 205$ \\ 9950 B.c.
}

Marine shell (Arctica islandica) from late-glacial marine clayey silt, at junction between laminated basal part and homogeneous upper part, alt 7.42 to $7.75 \mathrm{~m}$, Cardross, Dumbartonshire, Scotland $\left(55^{\circ} 58^{\prime} \mathrm{N}\right.$ Lat, $4^{\circ} 40^{\prime} \mathrm{W}$ Long). Coll. 1967 and subm. by J. Rose, Univ. of Glasglow. Comment (J.R.): recent radiocarbon dates from marine shells obtained from Loch Lomond $(11,700 \pm 170, \mathrm{I}-2235)$ and the upper Forth $(11,800$ \pm 170 , I-2234) (Sissons, 1967) indicate that low land in Forth and Clyde basins $\mathrm{N}$ and $\mathrm{E}$ of Cardross were submerged ca. 11,800 yr ago. Cardross date agrees with these results. Relationship to stratigraphy indicates that at this time Late Weichsel ice was melting from middle Clyde Estuary with glacier margin floating in a high, late-glacial sea. Another sample from same locality dated at Univ. of Glasgow yielded 11,787 \pm 122 .

\section{N-487. Bossall}

$3020 \pm 110$

Peat at depth $3 \mathrm{ft}$ from exposure in small terrace at $+75 \mathrm{ft}$ at side of Barnby Carr stream at Bossall, near Malton, Yorkshire, England $\left(54^{\circ}\right.$ 02' N Lat, $0^{\circ} 54^{\prime} \mathrm{W}$ Long). Coll. 1968 and subm. by B. Matthews, Soil Survey of England and Wales.

\section{N-488. East Moor SE66/0840}

$$
\begin{aligned}
& 10,700 \pm 190 \\
& 8750 \text { B.c. }
\end{aligned}
$$

Peat $5 \mathrm{ft} 6 \mathrm{in}$. from borehole at $+80 \mathrm{ft}$ at East Moor, near York ( $54^{\circ} 04^{\prime} \mathrm{N}$ Lat, $1^{\circ} 06^{\prime} \mathrm{W}$ Long). Coll. 1968 and subm. by B. Matthews.

\section{N-558. Otley}

$4910 \pm 125$

Wood near human remains $6 \mathrm{ft}$ above Wharfe R., at depth $12 \mathrm{ft}$ from side of gravel quarry, near Otley, Yorkshire $\left(53^{\circ} 55^{\prime} \mathrm{N}\right.$ Lat, $1^{\circ} 43^{\prime} \mathrm{W}$ Long), from lacustrine silt containing tree trunks, nuts, beetles, assoc. with complete $6 \mathrm{ft}$ human skeleton. Coll. 1968 and subm. by B. Matthews.

\section{ARCHAEOLOGIC SAMPLES}

\section{A. Japan}

\section{N-453. Mitanda}

Charcoal from shell layer 30 to $50 \mathrm{~cm}$ thick at Mitanda shell mound, Katsuta city, Ibaragi pref. ( $36^{\circ} 21^{\prime} \mathrm{N}$ Lat, $140^{\circ} 33^{\prime} \mathrm{E}$ Long). Shell layer underlain by loam and contains pottery of Later Middle Jomon period. Coll. 1967 and subm. by M. Nishimura, Waseda Univ. 


\section{Okitsu series}

Material from shell layer containing Early Jomon pottery of Okitsu type, at Okitsu shell mound, Tenjinkubo, Okitsu, Miho-mura, Inashikigun, Ibaragi pref. (35 59' $\mathrm{N}$ Lat, $140^{\circ} 18^{\prime} \mathrm{E}$ Long). Coll. 1967 and subm. by M. Nishimura. Comment: marine shell from same shell mound yielded $4880 \pm 130$ (N-175, Radiocarbon, 1966, v. 8, p. 333).

\section{N-454a. Okitsu 1}

$5100 \pm 135$

Charcoal fragment on shell surface at Trench $\mathbf{B}$.

3150 в.C.

\section{N-454b. Okitsu 2}

$4780 \pm 125$

2830 B.c.

Charcoal fragment and carbon powder on potsherd at Trench G.

\section{N-458. Okitsu 3}

Fresh water (Corbicula japonica) and marine shell (Meretrix lusoria) assoc. with N-454a.

\section{N-514. Kayama}

$7080 \pm 150$

5130 в.C.

Carbon in pottery matrix of potsherd from Kayama shell mound, Sawara, Yokosuka city, Kanagawa pref. ( $35^{\circ} 14^{\prime} \mathrm{N}$ Lat, $139^{\circ} 41^{\prime} \mathrm{E}$ Long), in shell layer, 160 to $180 \mathrm{~cm}$ thick, overlying loam. Coll. 1948 and subm. by M. Nishimura. Pottery is of Earliest Jomon, Kayama type. Comment: marine shell assoc. with same type pottery yielded $6740 \pm 150(\mathrm{~N}-368$, Radiocarbon, 1968 , v. 10, p. 340).

\section{Kumadzulo series}

\section{B. Africa}

Portions of burnt wall posts from early Iron age village site near Sekuti, Zambia (17 $37^{\prime}$ S Lat, $25^{\circ} 32^{\prime}$ E Long). Coll. 1967 and subm. by J. O. Vogel, Livingstone Mus., Zambia.

\section{N-408. Kumadzulo 1 ZLm-1}

Material from scatter of burnt wood $24 \mathrm{in.} \mathrm{deep} \mathrm{at} \mathrm{interface} \mathrm{of}$ village midden with underlying sterile Kalahari sands. Comment (J.O.V.): date too early to be assoc. with this series. Assumed to predate village since it probably dates natural phenomenon.

\section{N-409. Kumadzulo 2 ZLm-2}

$1520 \pm 110$

Charcoal from Hut 3, assoc. with debris, contained piece of trade glass.

$$
\text { A.D. } 430
$$

$1390 \pm 110$

N-410. Kumadzulo 3 ZLm-3 A.D. 560

Charcoal from Hut 5. 
N-411. Kumadzulo 4 ZLm-4

Charcoal from Hut 6.

N-412. Kumadzulo 5 ZLm-5

Charcoal from Hut 8.

N-413. Kumadzulo 6 ZLm-6

Charcoal from Hut 12.

N-414. Kumadzulo 7 ZLm-7

Charcoal from Hut 1 .

General Comment (J.O.V.): although topologically not earliest manifestation along periphery of Zambesi Valley, ceramics from Kumadzulo appear to retain some characteristics of channel decorated tradition and would slightly predate ceramic assemblage at Dambwa. If dates are representative of occupation, they are average of early 7 th century.

\section{Kamangoza series}

Charcoal from stratified Iron age village site at Kamangoza, 1/4 mi of Kumadzulo (17 $37^{\circ} \mathrm{S}$ Lat, $25^{\circ} 32^{\prime} \mathrm{E}$ Long). It contains basal horizon which may be typologically related to Kumadzulo, covered by $4 \mathrm{ft}$ of Kalomo culture accumulation divisible stratigraphically into Kalomo a and Kalomo b horizon (at ca. 1.6 and $3.1 \mathrm{ft}$ depth). Coll. 1967 and subm. by J. O. Vogel.

\section{N-415. Kamangoza 1 ZLm-8}

$1030 \pm 110$

Charcoal from suspected village level, at depth $48 \mathrm{in}$.

N-416. Kamangoza 2 ZLm-9 A.D. 920

Charcoal from hearth containing bone carvings and early pottery, at depth 48 in.

\section{N-417. Kamangoza 3 ZLm-10 and 11}

$1025 \pm 115$

Charcoal from yellow sand zone with early pottery.

N-419. Kamangoza 5 ZLm-12

Charcoal at 36 in. depth.

N-420. Kamangoza 6 ZLm-13

Charcoal at 42 in. depth.

N-4.21. Kamangoza 7 ZLm-14

Charcoal at 42 in. depth.

\section{A.D. 925}

$$
935 \pm 105
$$

A.D. 1015

$$
1150 \pm 110
$$

A.D. 800

A.D. 1040 
N-423. Kamangoza 9 ZLm-16

Charcoal at 18 in. depth.

N.424. Kamangoza 10 ZLm-17

Charcoal at 24 in. depth.

\section{N-425. Kamangoza 11 ZLm-18}

Charcoal at 24 in. depth.

\section{N.426. Kamangoza 12 ZLm-19}

Charcoal at 24 in. depth.

N-455. Kamangoza 13 ZLm-20 and 21 Charcoal at $>50$ in. depth.

\section{N-457. Kamangoza 14 ZLm-22}

Charcoal at 36 in. depth.

General Comment (J.O.V.): although stratigraphically inconsistent due to intensive nature of early phases of mound occupation, series forms a close group suggesting that earliest village horizons on site are contained within 200 yr span from middle 9th to 11 th centuries. Series parallels dates from Isamu Pati, and suggests slightly earlier occurrence of typical middle Isamu Pati type ceramics.

\section{Urewe series}

Charcoal from red brick-earth at Urewe, Nyanza Prov., Kenya $\left(0^{\circ}\right.$ $02^{\prime} \mathrm{N}$ Lat, $34^{\circ} 20^{\prime} \mathrm{E}$ Long), assoc. with Early Iron age "Dimple-based pottery" (Leaky, Owen, and Leaky, 1948; Soper, 1967). Coll. 1967 and subm. by R. C. Soper, Brit. Inst. Hist. and Archaeol. E. Africa.

\section{N-435. Urewe (Ulore II) A}

Charcoal at $60 \mathrm{~cm}$ depth.

N-436. Urewe (Ulore II) B

Charcoal at 60 to $80 \mathrm{~cm}$ depth.

\section{N-437. Yala Alego (Kang'uen II)}

Charcoal at 15 to $30 \mathrm{~cm}$ clepth in red brick-earth assoc. with "Dimplebased pottery" at Yala Alego, 51/2 mi S of Urewe, Nyanza Prov., Kenya ( $0^{\circ} 02^{\prime} \mathrm{S}$ Lat, $34^{\circ} 20^{\prime}$ E Long). Coll. 1967 and subm. by R. C. Soper.

General Comment on N-435-437 (R.C.S.): above dates agree with recent dates from Ruanda-Urundi in demonstrating early 1st millennium date of Early Iron age in interlacustrine area.

N-482. Kamunyu K-1 MU $1 / 454$

$2360 \pm 115$

410 B.C.

Charcoal from Kamunyu, Murang'a Dist., Kenya $\left(0^{\circ} 46^{\prime} \mathrm{S}\right.$ Lat, $36^{\circ}$ 
$51^{\prime}$ E Long), at ca. $40 \mathrm{~cm}$ depth in sunken hearth, assoc. with pit feature traditionally attributed to Gumba people, pre-Kikuyu inhabitants. Obsidian implements and pottery of little known type found in pit. Coll. 1968 by B. Golden; subm. by R. C. Soper. Comment (R.C.S.): date is unexpectedly early, but is unchecked by independent dating.

\section{N-483. Kwale Forest Site KW FS 68 (3)}

$$
1850 \pm 115
$$

Charcoal from Kwale Forest site, Kwale Dist., Kenya ( $4^{\circ} 11^{\prime} \mathrm{S}$ Lat, $39^{\circ} 26^{\prime} \mathrm{E}$ Long), at 30 to $40 \mathrm{~cm}$ depth, assoc. with sherds of Early Iron age Kwale ware and some iron-smelting debris. Coll. and subm. 1968 by R. C. Soper.

\section{N-484. Kwale Ditch Site KW DS 68 (3)}

$1780 \pm 115$

Charcoal from Kwale Ditch site, Kwale Dist., Kenya (4 $12^{\prime} \mathrm{S}$ Lat, $39^{\circ} 26^{\prime}$ E Long), at 25 to $35 \mathrm{~cm}$ depth. Assoc. as for N-483. Coll. and subm. 1968 by R. C. Soper. Comment (R.C.S.): above 2 sites are in same area as, and broadly contemporary with original Kwale site dated by N-291 and 292 (Radiocarbon, 1968, v. 10, p. 343).

\section{N-485. Kwale Game Moat KW PTH 68}

Charcoal from Kwale Game Moat, Kwale Dist., Kenya (4 $11^{\prime} \mathrm{S}$ Lat, $39^{\circ} 26^{\prime} \mathrm{E}$ Long), at $50 \mathrm{~cm}$ depth in sec. of Game Moat, not assoc. with cultural material. Coll. and subm. 1968 by R. C. Soper. Comment (R.C.S.): material originally considered to originate from forest clearance and/or charcoal burning carried out by Early Iron age inhabitants around settlement, but now shown to be too early.

\section{Gundu and Ndonde series}

Charcoal from Iron age mound at Gundu (16 $6^{\circ} 45^{\prime} \mathrm{S}$ Lat, $27^{\circ} 17^{\prime}$ E Long) and Ndonde (16 $44^{\prime} \mathrm{S}$ Lat, $27^{\circ} 24^{\prime} \mathrm{E}$ Long), near Batoka, Zambia. Early Iron age levels overlain by Kalomo culture horizons and early Tonga occupation (Fagan, 1967). Coll. and subm. 1967 by B. M. Fagan, Univ. of California.

\section{N-427. Gundu $1 \quad \mathrm{RC} / \mathrm{I} / \mathbf{1 5}$}

$1100 \pm 110$ culture.

Charcoal from hearth? pit, 77 in. deep, assoc. with Mid-Kalomo

\section{N-428. Gundu 2 RC/II/01}

A.D. 1015

$935 \pm 105$

Charcoal at 18 in. depth, assoc. with Mid-Kalomo culture.

N.429. Gundu $3 \quad \mathrm{RC} / \mathrm{I} / 16$

$$
825 \pm 105
$$

Charcoal on bed rock, assoc. with Early Iron age culture.

N-430. Gundu 4 RC/III/04

$1200 \pm 110$

Charcoal at 3 in. below Kalomo interface. 
N-431. Gundu $5 \quad \mathrm{RC} / \mathrm{III} / 06$

Charcoal assoc. with grooved ware near bedrock.

N-432. Ndonde 1 ND/RC/6

Charcoal at 11 in. depth, assoc. with Kangila ware.

N.433. Ndonde 2 ND/RC/7

Charcoal at 22 in. depth, assoc. with Kalomo? ware.

N-434. Ndonde $3 \mathrm{ND} / \mathrm{RC} / \mathbf{1 0}$

Charcoal at 46 in. depth, near base.

General Comment (B.M.F.): N-434 is too early; others confirm date from early Tonga of ca. 1100 to 1200 A.D. and for Kalomo-type ware of late 1st millennium A.D. This sequence compares well with others of Kalomo sequence (Fagan, 1967) and that of Victoria Falls area near Zambesi.

\section{Uvinza series}

Charcoal-bearing soil from Pwaga $5^{\circ} 04^{\prime} \mathrm{S}$ Lat, $30^{\circ} 23^{\prime} \mathrm{E}$ Long) and Nyamsunga $\left(5^{\circ} 06^{\prime} \mathrm{S}\right.$ Lat, $30^{\circ} 23^{\prime}$ E Long), Uvinza Salt Springs, W Tanzania. Coll. 1967 and subm. by J. E. G. Sutton, Univ. College, Dar es Salaam. Comment: dated on total organic material.

\section{N.461. Pwaga 1}

A.D. 1740

$210 \pm 110$

Dark, ashy soil from layer of intensive salt-working, $0.43 \mathrm{~m}$ deep, assoc. with Uvinza Class $\mathrm{C}$ pottery typified by moulded rims and rouletted decoration. Comment (J.E.G.S.): industry is confirmed connected with 19th century caravan trade and continued in fact till 1903.

\section{N-462. Pwaga 2}

A.D. 1185

$765 \pm 105$

Chocolate clayey soil from layer containing Uvinza Class B pottery, stratified below Class C, at $0.99 \mathrm{~m}$ depth. Comment (J.E.G.S.): rouletted decorated pottery is considered to belong to 2nd millennium A.D. Earliest radiocarbon date previously obtained is of 14 th century from Bigo, W Uganda (GXO-519).

\section{N-463. Pwaga 3}

$1530 \pm 160$

Chocolate clayey soil from layer containing Uvinza Class A pottery, $1.32 \mathrm{~m}$ deep. Comment (J.E.G.S.): pottery is of Early Iron age with clear affinities to "dimple-based" wares, especially those of Uganda-Tanzania border and Ruanda. Date indicates long history of salt working at Uvinza brine-springs.

\section{N-464. Nyamsunga 1}

$260 \pm 110$

Chocolate clayey soil at $1.17 \mathrm{~m}$ depth.
A.D. 1690 
N-465. Nyamsunga 2

$1360 \pm 200$

Chocolate clayey soil at $1.35 \mathrm{~m}$ depth.

A.D. 590

General Comment (J.E.G.S.): both samples are from layer containing Uvinza Class A pottery, with Early Iron age affinities, similar to that of lowest layer at Pwaga. N-464 is ca. 1000 yr too late.

\section{Benin City series}

Material from remains at Benin city, Nigeria $\left(6^{\circ} 20^{\prime} \mathrm{N}\right.$ Lat, $5^{\circ} 37^{\prime}$ E Long). Coll. 1963 by G. E. Connah; subm. 1967 by T. Shaw, Univ. of Ibadan (Connah, 1967).

\section{N-376. Benin City 1 UI 671}

A.D. 1230

$720 \pm 105$

Timber from well-shaft, $31 \mathrm{ft} 2 \mathrm{in}$. below bottom of Cutting II, at Clark's Quarters site.

\section{N-377. Benin City 2 UI 672}

A.D. 1180

$$
770 \pm 105
$$

Charcoal from well-shaft, among mass burial, at Clark's Quarters site, Cutting II.

\section{N-378. Benin City 3 UI 673}

A.D. 1305

$$
645 \pm 105
$$

Charcoal from Spit 9 in pit-fill at Benin Mus. site, Cutting XIV.

\section{N-379. Benin City 4 UI 674}

A.D. 1340

$$
610 \pm 105
$$

Charcoal from old ground surface beneath city wall.

\section{N-380. Benin City 5 UI 675}

A.D. 1500

Charcoal from well-filling belonging to early phase of site. General Comment (T.S.): dates occupation of Usama palace.

\section{Yelwa series}

Material from remains on $\mathrm{W}$ bank of Niger R., $4 \mathrm{mi}$ downstream from Yelwa, Sokoto Prov., N Nigeria (10 $49^{\prime} \mathrm{N}$ Lat, $4^{\circ} 42^{\prime} \mathrm{E}$ Long). Coll. 1966 by A. J. Priddy; subm. by T. Shaw, Univ. of Ibadan.

N-361. Yelwa 1 UI 676

Charcoal from A $114 / 5,3 \mathrm{ft}$ deep.

N.362. Yelwa 2 UI 677

Charcoal from A $163,1 \mathrm{ft} 6$ in. to $2 \mathrm{ft} 7$ in. deep.

N-363. Yelwa 3 UI 678

Charcoal from A $164,2 \mathrm{ft} 8$ in. to $3 \mathrm{ft} 8$ in. deep.

N-364. Yelwa 4 UI 679

Charcoal from A $166,4 \mathrm{ft} 5$ in. to $6 \mathrm{ft} 3$ in. deep.
$1850 \pm 115$

A.D. 100

$$
1490 \pm 115
$$

\section{A.D. 460}
$1310 \pm 110$ A.D. 640

$$
1750 \pm 110
$$

A.D. 200 


\section{Yau series}

Charcoal from mound at Yau, Bornu, NE Nigeria $\left(13^{\circ} 34^{\prime} \mathrm{N}\right.$ Lat, $13^{\circ} 15^{\prime}$ E Long). Coll. 1965 by G. Connah; subm. 1968 by T. Shaw (1966).

N-476. Yau 1 UI 681

From base of mound.

N-477. Yau 2 UI 682

From top of mound.

\section{N-478. Yau 3 UI 683}

From surface beneath mound.

\section{N.479. Yau 4 UI 684}

N-480. Kursakata
$1100 \pm 110$ A.D. 850

$675 \pm 110$

A.D. 1275

$$
1020 \pm 90
$$

A.D. 930

$$
\begin{aligned}
& 990 \pm 110 \\
& \text { A.D. } 960 \\
& 2880 \pm 140 \\
& 930 \text { B.C. }
\end{aligned}
$$

Charcoal from base of mound at Kursakata, Bornu, NE Nigeria $\left(12^{\circ}\right.$ $19^{\prime} \mathrm{N}$ Lat, $14^{\circ} 14^{\prime}$ E Long). Coll. 1965 by G. Connah; subm. 1968 by T. Shaw.

\section{N.481. Birnin Gazargamo}

$330 \pm 105$

Charcoal from middle to lower part of mound at Birnin Gazargamo, Bornu, NE Nigeria (13० $0^{\prime} \mathrm{N}$ Lat, $12^{\circ} 18^{\prime} \mathrm{E}$ Long). Coll. 1965 by G. Connah; subm. by T. Shaw.

Date lists:
$\begin{array}{ll}\text { Riken II } & \text { Yamasaki, Hamada, and Fujiyama, 1966 } \\ \text { Riken III } & \text { Yamasaki, Hamada, and Fujiyama, 196 }\end{array}$
Riken IV Yamasaki, Hamada, and Fujiyama, 1968

Connah, G., 1967, Archaeological research in Benin City 1961-64: Hist. Soc. of Nigeria Jour., v. 2, no. 4.

Fagan, B. M., 1967, Iron age cultures in Zambia-I, London.

Konishi, K., Omura, A., and Kimura, T., 1968, ${ }^{231} \mathrm{U}^{2}{ }^{230} \mathrm{Th}$ Ages of some Late Quaternary coralline limestones from southern Taiwan (Formosa), in: Geol. and Palaeont. Southeast Asia, Kobayashi, T. and Toriyama, R., (eds.), v. 5, p. 211-224, Univ. Tokyo Press.

Leaky, M. D., Owen, W. E., and Leaky, L. S. B., 1948, Dimple-based pottery from Central Kavirondo, Kenya: Coryndon Memorial Mus. Occasional Papers, no. 2.

Omura, A., Konishi, K., and Hamada, T., 1969, Comparison of ${ }^{14} \mathrm{C}$ with ${ }^{230} \mathrm{Th}$ and ${ }^{231} \mathrm{~Pa}$ ages in some Hermatypic Corals: Fossils, v. 15 (Special issue on Isotope Palacontology), in press.

Shaw, T., 1966, Northern History Research Scheme-First Interim Report: Zaria.

Sissons, J. B., 1967, Glacial stages and radiocarbon dates in Scotland: Scottish Jour. Geol., v. 3, p. 375-381.

Soper, R. C., 1967, Early Iron age pottery types from East Africa; comparative analysis: Paper, 6th Panafrican Cong. of Prehistory, Dakar.

Yamasaki, Fumio, Hamada, Tatsuji, and Fujiyama, Chikako, 1966, RIKEN natural radiocarbon measurements II: Radiocarbon, v. 8, p. 324-339.

1967, RIKEN natural radiocarbon measurements III: Radiocarbon, v. 9, p. 301-308.

p. $333-345$. 